\title{
Borders of engagement
}

Territorial boundaries may vary even though the formal lines on maps remain unchanged; the meaning attached to those boundaries in the image of the state may be challenged in a variety of ways (Migdal 2001:26).

This book attempts to incorporate several bodies of literature that all, in various ways, focus on making sense of the ambivalent relationship between state authority and local authority along state edges - in this case literal state borders and its borderlands. Such a framework aims to encompass macro and micro interactions between the local agency of border populations and the regulatory structures of state governance. In order to identify the special milieu (or social field) where local agency is enacted, the book discusses the various ways state borders and adjacent borderlands are conceptualized within recent scholarly debates. The book will pay special attention to ongoing debates concerning Southeast Asian borderlands. Within these debates, the idea of 'the state', as seen from the borderland and its population, inevitably takes a central position. Afterwards the book elaborates on the value of applying a processoriented approach as an overall frame for understanding the complexities and social dynamics in the borderland setting.

The extensive literature on border studies is spread across many disciplinary fields, and there are just as many ways of approaching the subject. The approach of this study is primarily inspired by anthropological studies that embrace different attempts to theorize on the dynamics of state borders, adjoining borderlands and their populations. Here state borders are not merely lines drawn on maps where the nation-state enforces its outer territorial sovereignty and imposes its strict authority, 
but also places of intricate local agency. ${ }^{1}$ The object of this research is not the border itself, that bold line drawn on maps, but the practices and opportunities for local agency it fosters.

\section{BORDERS AND BORDERLANDS}

Studies on the political and economic aspects of border regions within the social sciences have traditionally taken a top-down approach, mostly focusing on state-level activities, especially on the ways in which states deal with borders and their populations by exercising control and exerting power. The emphasis of these studies has generally been centreperiphery approaches. Here the periphery was portrayed as passive, and relationships between border communities and the centre were analyzed within the rhetoric of resistance and domination. ${ }^{2}$ Scholars paid little attention to the local practices of populations living in close proximity to state borders and how these communities negotiated with state authority and shaped the borderland environment (Campbell and Heyman 2007).

There has been a pronounced tendency within social sciences to marginalize these border regions and their populations (Haller and Donnan 2000; Van Schendel 2005). According to Hastings Donnan and Thomas Wilson, 'These local border communities are not simply the passive beneficiaries or victims of world statecraft' (Donnan and Wilson 1994). Because of this failure to appreciate the everyday subtleties of statesociety interaction, border regions are often stereotypically displayed as places of strict regulation. Such narrow views do little justice to the intricate ways of local lives. ${ }^{3}$ Views of an imagined distant 'state' somewhere asserting its regulative power at its borders are of course useful and tell important stories about repression, domination and power, but as this study shows they tell only a partial story. ${ }^{4}$

Since the mid-1990s state borders and borderlands have been subject

\footnotetext{
$1 \quad$ See, for example, anthropologists Alvarez 1995; Baud and Van Schendel 1997; Donnan and Wilson 1994 and 1999; Haller and Donnan 2000; Rösler and Wendl 1999; Wilson and Donnan 1998a.

2 For a critique of the state-centric, centre-periphery approach, see Donnan and Haller 2000:10; Walker 1999:5.

3 I am aware of the shortcomings in using the binary distinction between state and society, but for the sake of clarity, I will stick with these categories for now and explain their shortcomings as my analysis proceeds.

4 For a comprehensive review of border studies within anthropology, see Alvarez 1995; Donnan and Wilson 1999; Wadley 2002a; Wilson and Donnan 1998a.
} 
to growing interest within the social sciences, not least among anthropologists who have begun to redress the one-sidedness of state-centred studies by recognizing border regions as laboratories of social and cultural change (Baud and Van Schendel 1997:235). ${ }^{5}$ This perspective has been referred to as 'the anthropology of borders' (Rösler and Wendl 1999:61; Wilson and Donnan 1998a:3) or 'the anthropology of borderlands' (Alvarez 1995).

Following these research trajectories, this study attempts to turn the argument around and to promote an understanding of borderland processes and state formation from the point of view of local agents living there. By approaching international borders and borderlands from below, as structures of opportunity, the study show how borderlands are places where people and ideas meet, new things come into being, and complex socio-political change occurs, despite the apparent rigid control and rules of government bureaucracy. In an attempt to conceptualize the distinctiveness of border regions and move beyond static perspectives of the hegemonic and repressive state, several 'border' scholars began developing the concept of borderlands, which has become of central importance in order to create a common foundation for studying the dynamics unravelling along state borders. They argue that the functions of borders are basically similar everywhere; they separate national territories and control and regulate the flow of people and goods between these territories (Rösler and Wendl 1999). Although still a heavily debated concept, broadly speaking, what characterises a region as a borderland is the close proximity to a state borderline and the direct and significant effect economically, socially and politically this border has on life in the region. This follows the definition by Robert Alvarez that considers 'the borderlands as a region and set of practices defined and determined by this border' (Alvarez 1995:448). ${ }^{6}$

Discussing borderlands as a common term for a certain region implies that these borderlands have something in common from place to place, some similar characteristics. In his efforts to show the universality of border phenomena and to create a conceptual framework to under-

5 International or state borders have traditionally been the study subject of the political sciences (Bath 1976; Prescott 1987) and political geography (Grundy-Warr 1990; Minghi 1963), who generally have analyzed the subject of borders from the outset of the nation-state and based on descriptive and historical analysis of border demarcations. Here border studies became rather static and deterministic. $6 \quad$ For similar definitions, see also Baud and Van Schendel 1997; Martínez 1994b; Rösler and Wendl 1999; Van Schendel and Abraham 2005. 
stand these, Oscar Martínez has argued that ' the determining influence of the border makes the lives of border peoples functionally similar' (Martínez 1995a:xviii). ${ }^{7}$ He has proposed several key characteristics, which when combined constitute and shape what he calls the overall 'borderlands milieu' (Martínez 1994b:8). These characteristics are meant to be very general because of the infinite borderland variations and the heterogeneity of borderland contexts.

In the following, I have chosen briefly to elaborate on a few such characteristics, which are all relevant when discussing most Southeast Asian borderlands and in particular the West Kalimantan borderland. It is important to note that the characteristics presented by Martinez are based on studies of the highly unsymmetrical Mexican-US borderland, a context that resembles the Indonesian-Malaysian context. The main similarities are that both the Mexican and Indonesian (weaker) states border wealthier (stronger) states, the United States and Malaysia. This economic disparity inevitably results in an asymmetrical flow of people and resources between the two states. However, such asymmetrical characteristics might be less obvious in a European context, for example, where state authority along borders is usually much stronger, and the economic and political differences between bordering states are less pronounced. The reality is that not all border communities are divided by the border in the same way (Wilson and Donnan 1998b:14).

Located at the edge of a nation-state close to a foreign country, the borderland is situated in a transnational atmosphere, creating certain possibilities and opportunities for local populations that are often unavailable to populations farther inside the countries. Border populations are largely affected by, and participate in cross-border interaction, be it economic, social, or cultural interaction. Transnational interaction materializes in many different ways. For the border population studied here, interaction such as cross-border trading, smuggling, labour migration, socializing, and visiting friends and kin on the opposite side are main characteristics of their daily transnational lives. Further, a high degree of ethnic or cultural similarity among people of adjacent borderlands is found throughout Southeast Asia and plays a crucial role in understanding local borderland strategies (Skeldon 1999:9). For example, Iban connections to similar ethnic populations on the other side of the

\footnotetext{
7 Several other border scholars recognize a similar shared 'border experience' among border people
} (Donnan and Haller 2000:15; Donnan and Wilson 1999:12). 
border enhance transnational interaction and create alternative possibilities for cross-border activity, which often circumvents official state rules (Martínez 1994a:10).

Because of their geographical location, borderlands are especially vulnerable when disputes with neighbouring countries occur. Struggle over territory or politics can end up turning borderlands into battlefields, often meaning that local populations become subject to attacks from both their own co-citizens and foreigners. Caught in the struggle between two conflicting parties, these populations are often forced to choose to be loyal towards one party, leading to violent repercussions from the other (Martínez 1994a:13). Another general characteristic that permeates local lives in the borderland is the sense of being pulled in several directions at once, both from within their own state, in which they reside, and from the neighbouring state, with which they are often economically and socially connected. From which side of the border the pull is stronger depends on the degree of interaction and relationships, economic, social and cultural (Martínez 1994b:12). For a majority of border populations connections across the border often seem stronger than those within their own national heartland, which often results in weaker national self-identification. Politically, these populations belong to a state that demands their unswerving loyalty, but economically, ethnically and emotionally they often feel part of another, non-state entity (Baud and Van Schendel 1997:233).

According to Martínez, the border populations with the weakest loyalty towards their own state are often those with the strongest crossborder ties (Martínez 1994a:19). This is very much the case in connection with the Iban in Kalimantan, whose strong ethnic and kinship links across the border in Sarawak determine their direction of relationship. Their sentiments are primarily connected to the social and economic processes in the adjacent Sarawak state rather than to their own distant provincial or national heartland. While such cross-border attachment is most evident among the Kalimantan Iban their kin on the Sarawak side of the border do not show such strong attachment towards Kalimantan. On the contrary, the Sarawak Iban living just across the border seems to display a strong identification with Sarawak and feel much more integrated into the Malaysian state.

The sense of otherness in connection with the national state, as experienced by some border populations, is further increased because 
of their often diverse and conflicting interests. Many do not think of themselves as part of a large national unity and often feel that a distant political centre does not understand the special circumstances of living in a borderland. Subsequently, they may feel less obligated or bound to follow national laws. Often border populations continue their cross-border economic links, although doing so may subvert national rules and policy through such actions. In many cases, they do not have any other option because their national government has not succeeded in integrating the borderland into the larger national economy (Baud and Van Schendel 1997:229). Therefore, there may be a tendency to bend, ignore and breach laws that they feel are interfering with their interests and special way of life. Government regulations at state borders, which in different ways at least formally attempt to put restrictions on cross-border interaction, may lead to different kinds of conflict and rule bending (Martínez 1994b:12). To breach trade and immigrant regulations is, for example, a common and, by border populations, acceptable praxis (Flynn 1997). The border, by its very nature of dividing two separate nation-states with their often different administrative and regulatory regimes, generates a kind of opportunity structure that invites illicit actions such as smuggling and illegal immigration (Anderson and O'Dowd 1999:597). Smuggling and illicit trade is often described as the borderland occupation par excellence (Rösler and Wendl 1999:13). ${ }^{8}$

This distinctive environment of the border is characterised by its ambivalent nature of being both uniting and dividing. Borders can be viewed as an economic opportunity whereby a two-way flow of goods and workers brings development. It can also be 'abused' for economic gain through import and export, such as the smuggling of timber over the border to Sarawak from West Kalimantan. The illegal processes taking place at borders have been referred to as a subversive economy. Donnan and Wilson note how such a second economy provides an important livelihood for many border populations and is sometimes the most important economic factor of the border region (Donnan and Wilson 1999).

As indicated above, life in the borderland seems to generate common interests among people living there that promote transnational practices (such as timber smuggling) that by the local population itself

8 For a similar statement, see also Baud and Van Schendel 1997:230-1; Driessen 1999:117. 
are considered acceptable (licit), but, more often than not, declared illegal by their states (Galemba 2008:21). Investigating such an apparent conflict of perceptions between border people and powerful state interests is a useful point of entry into exploring the limitations of top-down perspectives of 'seeing like a state' along national borders. ${ }^{9}$ In order to cast light on the logic behind state interventions, the practice of governance and the power relations entangled in such within the borderland setting, discussions of state governance and its various configurations on the border become central aspects in the analysis. This will also aid in the understanding of the exercise of governmental rationality as imposed by the various authorities entering the borderland who attempt to govern border people in the name of development (see Chapter 7). This analytical frame also underscores the fact that governmental interventions do not always achieve their goals and often have unintended effects as they are transformed through local social, cultural and economic processes.

Within this overall approach to borderlands, there is a shared understanding that borders create certain unique physical, political, and economic circumstances not seen in areas farther removed from the border. These circumstances give rise to cross-border strategies and interaction that among border populations often result in ambivalent attitudes towards their nation-state. Here the primary focus has shifted from the state level and issues of state-related security and sovereignty, to a focus on the practice of border people and their dialectic relationship to shifting government authorities.

\section{STATE FORMATION FROM BELOW}

[...] There is no neat dichotomy of formal/government on the one hand, and informal/non-government on the other. Reality is messier (Lund 2006a:699).

Besides these more general interests in conceptualizing borders and borderlands within anthropology and social sciences in general, there is 
a burgeoning ethnographic literature on Southeast Asian borderlands. ${ }^{10}$ Building on the above insights, these studies take the vantage point of border narratives in finding new ways to re-conceptualize the concept of 'the state' and emancipating themselves from state centrist views. ${ }^{11}$

Matthew Amster, in his studies of the borderlands of Malaysia and Indonesia, has (among other scholars) pointed out the helpfulness of meticulous ethnographic case studies in highlighting localized processes through which mechanisms of state control are articulated, reaffirmed, resisted, and manipulated (Amster 2005b:24).

The main emphasis is here put on state definitions as negotiated and contested. This approach offers a conceptual framework with which to imagine how we might loosen the tight grip of 'the state'. This view of the state fits well into another line of recent studies within anthropology and international studies. Although not necessarily taking borderlands as their analytical departure point, these studies have taken up the challenge of conceptualizing the state as a series of effects rather as an a priori homogenous whole. ${ }^{12}$

According to Joel Migdal (2001), scholars within social sciences, predominantly political science, have long stressed the idea of the state as an autonomous unit. Inspired by a rigid reading of the 'ideal state' of Max Weber, these scholars focussed on the state as a unit that could be studied apart from society, an organization with 'extraordinary means to dominate'. Migdal notes that it was never Weber's intention that his definition of the 'ideal state' should be taken as a normal state; rather, it was to be understood as an heuristic 'ideal type state' (Migdal 2001:8-15). Despite this, the above conceptualizations of the state have largely become inherent within popular and academic discourses. They have been adopted readily and appropriated by state leaders to promote the idea

\footnotetext{
1o Studying international borders in Southeast Asia is a recent practice, and up until the late 1990s, little attention was paid to this approach among anthropologists (and other scholars) of the area (Horstmann 2002:2). Most regional studies of international borders have concentrated on the Americas (Martínez 1994a; 1994b), Africa (Asiwaju 1990; 1993; Nugent and Asiwaju 1996) and Europe (Anderson and O’Dowd 1999; Donnan and Wilson 2003; O’Dowd and Wilson 1996; Wilson 2005).

$1 \quad$ Amster 2006; Cooke 2009; Horstmann and Wadley 2006b; Ishikawa 2010; Schoenberger and Turner 2008; Sturgeon 2005; Tagliacozzo 2005; Walker 1999. Within these studies the margins are not only to be understood as a geographical locale but also as an analytical category, echoing Anna Tsing's definition that margins are to be understood as a: 'conceptual site from which to explore the imaginative quality and the specificity of local/global cultural formation' (Tsing 1994:279).

12 See Das and Poole 2004b; Ferguson and Gupta 2002; Gupta 1995; Hann and Dunn 1996; Hansen and Stepputat 2001; Lund 2007; Migdal 2001; Sharma and Gupta 2006; Wilson and Donnan $2005 a$.
} 
of the state as a strong and coherent entity. This idea has strengthened the illusion that their respective governments are representing 'the state'. Thus the state often becomes synonymous with government institutions and the perception blurs the fact that state representatives have multiple statuses and relationships. A good example is the New Order 'state' of former Indonesian President Soeharto. Much literature on the relationship between state and society during Soeharto's Indonesia took a statecentred approach. This approach had a tendency to take for granted the idea of a strong, solid and oppressive state and thereby to overestimate state power. ${ }^{13}$ As mentioned by Gerry van Klinken, many scholars were: 'blinded by the solid state' (Van Klinken 2001:265). The idea of an overly repressive state that dominates every aspect of local society has been widely debated during the post-Soeharto period and deemed to be simplistic. The breakdown of Soeharto's regime in 1998 clearly showed the fragmented character of the state and the more dynamic relationship between state and society. ${ }^{14}$

With a point of departure in state 'margins', Veena Das and Deborah Poole (2004) have suggested that we should distance ourselves from images of the state as bounded and imbued by an inherent rationality, detached from local practice. Instead, we should analyze how the regulatory practices of the state are embedded in and shaped by local practice (2004:2). ${ }^{15}$ Das and Poole note that state borders, as 'spaces of exception', are especially illustrative expressions of such state margins. Here they illuminate the pluralization of regulatory authorities (Das and Poole 2004:18-19). Likewise, Aradhana Sharma and Akhil Gupta (2006) point out that an analytical approach to state formation as culturally embedded avoids assumptions that the state stands at the 'apex of society' and is the source of all power (2006:8-9). As Wilson and Donnan put it, the state is no longer treated as 'an actor just off stage whose face is never seen but who has the ability to constrain or enable the actions of others' (Wilson and Donnan 2005b:2).

While we can learn much by seeing the state as grounded in everyday practices, it is still important to take into account that the idea of the unitary state still plays a major role as a potent symbol of power in local

\footnotetext{
13 For good examples of this tendency among scholars on New Order Indonesia, see Budiman 1990.

${ }_{14}$ For an overview of these early debates on state-society relations in Indonesia, see Van Klinken 2001.

15 Their analytical starting point is that the 'margins' of the state can be either the conceptual or literal territorial margins such as state borders (Das and Poole 2004a:3).
} 
imaginations (Gupta 1995:390; Hansen and Stepputat 2001: 5). In the West Kalimantan borderland, one commonly hears state authorities and community members mention that 'the state' imposes its control and power from above on local matters. State authorities widely employ the rhetoric of the state locally in legitimizing various acts of governance, but also as pretext for not acting at all. They may claim that 'this is not a district government matter but a matter of the central state; therefore our hands are tied'. At the same time, local communities often use the state rhetoric of development to justify acts of economic advancement through 'illegal' activities. To creatively employ and play with the rhetoric and symbols of the state is common practice and often used for local advantage (Das and Poole 2004a:20).

The concept of the state as an entity is continually reinforced and fortified (especially along borders) through various practices, images, symbols and rituals: territorial maps, border posts and markers, passports, military ceremonies and flag rising. See, for example, Migdal (2001:18) and Donnan and Wilson (1999:63-87). A central motivation for this book is to disaggregate this popular ideal of the unitary nation-state with its perceived fixed and regulated borders, territorial integrity, national control over national resources, bureaucratic and legal coherence, obedience to rules and laws, and loyal citizenry. I argue that all these elements that 'ideally' would make up a fully formed 'state' are always in 'formation'. Therefore, the fully formed state never is completed. Instead, state formation is a historical continuum, a fluid process of negotiation and contestation. This book attempts to show that borderland dynamics throw each of the above elements of the ideal state sharply into question.

In a paper on the difficulties of studying the state, Philip Abrams suggests that the state is best understood as 'an idea'. He proposes that it is more an ideological construct to be employed in exercising and legitimizing power than a real entity (Abrams 1988:75-6). As such, there are two interrelated aspects of the state: the state as constituted in local everyday practices, and the state as an idea visualised as a potent, monolithic source of power. Migdal elaborates on this point by noting the importance of analysing the state as a contradictory entity that is understood best on two levels - one that recognizes the powerful image of the state as a unified entity with clear boundaries and territory, and one that reunifies the state as bundles of loose fragments. He shows how the ill-defined boundaries between these fragments and other 
groupings working inside and outside literal state borders are 'often promoting conflicting sets of rules with one another and with "official" law' (Migdal 2001:22). In the words of Migdal, the state possesses an inherent paradox of simultaneously being: 'a part of society and apart from society' (Migdal 2004:18).

What makes these process-oriented approaches especially beneficial and useful as a framework for analysis is the way they help us to understand the diffuse and slippery concept of the state by studying it in conjunction with the everyday practices of negotiation and contestation between local-level state officials and local actors (Gupta 1995; Migdal 1994 and 2001). Migdal has very tellingly named this way of grasping state-society relations as the state-in-society approach (1994, 2001). Conventional dichotomies of state and society are breached, and the static image of the state as the all encompassing entity and the singular source of power is replaced by an approach that sees the state as bundles of everyday institutions and forms of rule. Here the reference is to the multiple ways the state is configured and practiced in the local milieu (Corbridge et al. 2005:5-7). The attempt in this book is to show the forms of these negotiations and contestations as they are worked out over time and affect borderland lives and livelihoods.

Before proceeding further, I must emphasize that although I highlight the importance of local agency I still acknowledge the immense importance of central state regulations and institutions in shaping local borderland lives. I acknowledge the profound inequalities of power and tremendous risks attached to borderland livelihood strategies (Chalfin 2001:133). The main point is that such top-down regulations and laws are often reshaped to fit local realities, and the outcomes differ from what was expected by policymakers in Jakarta. Migdal notes that state laws and regulations have to compete with many other and different forms of normative behaviour, 'often with utterly unexpected results for the societies that states purport to govern - and for the states themselves' (Migdal 2001:12). Additionally, some fragments of the state, such as the military, have often colluded with non-state actors to achieve their goals. Such alliances have acted to promote certain rules and orders that often differ widely from the official rules and regulations of the state. These alliances, coalitions, or networks contradict the portrayal of strict territorial and social boundaries that the state attempts to establish, 'as well as the sharp distinction 
between the state as pre-eminent rule maker and society as the recipient of those rules' (Migdal 2001:20).

Having arrived at perceptions of state power as fragmented and state formation as continually evolving thorough local-level negotiations with authority, I find it helpful to introduce the concept of authority. In particular, I want to ask how we should understand the relationship between state (government) and non-state forms of authority (authority exercised by local border elites) in arenas like the borderland where state authority at times either is largely absent or openly challenged.

Christian Lund (2006b) proposes an analytical strategy that focuses on such ambivalent arenas and the various institutions within them that exercise de facto 'public' authority but are not the state and as such manoeuvre in the twilight between state and society. These groupings he terms 'twilight institutions' (Lund 2006a:676-8). ${ }^{16}$ These 'twilight' institutions make it particularly difficult to draw a fine line between what is state and what is not. Within this framework Lund defines authority as 'an instance of power which seeks at least a minimum of voluntary compliance and is thus legitimated in some way' (2006a:678). As elaborated by Willem van Schendel and Itty Abraham, the absence of a strong state does not necessarily imply 'a state of disorder' but most often entails the presence of non-state and competing forms of authority with their own moral order (Abraham and Van Schendel 2005).

The Iban border elites and their networks of patronage are a vivid example of such non-state 'institutions' that exercise a kind of de facto authority as alternatives to the lack of functioning central state institutions. Local state officials often legitimize these institutions while the central state is less accommodating with what they term 'local' attempts to contest their authority. Further, as asserted by Lund, the local recognition of 'public' authority takes different forms and is often associated with the affirmation of control of a particular geographic area, in this case the borderland (2006b:694-5).

For example, local acts of vigilantism (see Chapter 6) are common in situations where the Iban population considers state institutions ineffective or inconsistent with local ways of life. Locals often express their claims of legitimacy by emphasizing their deep roots in the borderland. In that way they claim the right to profit from the border's advantages

16 Although Lund's analytical points are based on research in Africa, the dynamics he mentions are applicable to and relevant for a Southeast Asian setting. 
(Flynn 1997). They perceive the distant central state as an authority that does not understand the particular circumstances of life in the borderland and therefore the special practices it necessitates. This is especially so during periods of borderland history in which the politics of the central state have been experienced and portrayed as distinct and remote from the 'local arena' (Lund 2006b:688).

In their attempt to place local agency in the forefront of the study of Southeast Asian borderlands, Alexander Horstmann and Reed Wadley (2006b) mention the importance of recognizing that there are two sorts of narratives along state borders, one promulgated by the state and one by the border population. In accordance with the aforementioned studies on state and state formation, I will argue that these narratives are not necessarily disconnected as noted by Horstmann and Wadley but more often than not are intertwined and overlapping. This study assert that the intense focus on local agency within the new debates on borderlands has had a tendency to overemphasize the resistance of oppressed marginalized population along borders and to a certain degree neglected investigations into the question of how these local populations also engage in networks of collusion and other potentially rewarding relationships with various state authorities. Thus, it is not my intention to celebrate the 'weapons of the weak' but instead recognize that local relationships with the state should be understood as more than merely contentious (Horstmann and Wadley 2006a:17).

The borderland should not be seen solely as an arena of struggle between state and local communities - a place state power is a given, somehow suspended above local society. I instead propose to examine how state and local authorities are formed in tandem at the border. As such this study takes a slightly different approach from the majority of studies of borderlands mentioned above. I draw substantial regional inspiration from studies on Southeast Asian borderlands, like those of Andrew Walker (1996, 1999, 2006a) and Janet Sturgeon (1997, 2004, 2005), that enumerate many of the dynamics that I see to be similar to and of particular relevance to the study of the West Kalimantan borderland.

In his work on the borderlands of Laos, Thailand, China, and Burma, Walker provides an appealing regional perspective on how state regulatory practices are entangled with those of local communities. He shows how the outcome of what he refers to as 'technologies of rule' depend on the manner in which they are interpreted and put 
into play by lower-level government employees, elected representatives and others (Walker 1999). Walker highlights how various members of these 'frontier' communities often actively participate as collaborators in the regulation and maintenance of borders (1999:111-112). He argues that these collaborations are 'fluid and volatile' and that state officials should not be seen as [...] robotic agents of a hegemonic state (1999:112).

Walker's study accords well with Sturgeon's work on local 'border chiefs' and their engagement with state authorities in the borderlands of Burma, Thailand, and China. Sturgeon approaches these relations through historical analysis of control of access to resources and the means by which such relations take special configurations because they are enacted along an international border.

While differently argued, Sturgeon's work, like Walker's, takes a critical stance towards the series of border studies that emphasize a basic conflict between border communities and state officials. Instead of making presumptions that accentuate the state as exclusively restrictive of local cross-border strategies, she argues for much more complementarity in these relations (Sturgeon 2005:30). She discusses how state officials and border elites like village heads are joined in a 'complicated dance designed to meet the needs of each'. Here state official do not necessarily wish to eliminate local cross-border networks, be they legal or illegal, but instead collaborate with locals to take advantage of the opportunities and benefits these networks provide. ${ }^{17}$ The bargaining power of border elites and well connected entrepreneurs increases under circumstances where the access to resources is largely under their control and can lead to tacit tolerance by state agents of their 'criminal' activities as long as its suits these agents' needs (Smart 1999).

While Walker in his study portrays the strategic advantage of borderlands in a rather optimistic tone as zones of expanding economic opportunity, Sturgeon paints a somewhat murkier portrait of local opportunities. ${ }^{18}$ She highlights the success of well-connected border elites (small border chiefs) and how they position themselves as patrons negotiating access to valued resources through their lucrative relations with

\footnotetext{
17 Sturgeon 2004:466; 2005:32.

18 Walker later notes that his initial view of local community interaction with the state within the borderland studied might have been 'overly benign'. He confesses that he had paid insufficient attention to issues of class and ethnicity (Walker 2009:106).
} 
state officials and cross-border networks. Simultaneously, she underlines how the non-elite population (poor hill farmers) experience increasing marginalization and poverty. She refers to this phenomenon as 'predatory patronage' (Sturgeon 2004:482). A somewhat similar scenario of increasing inequality is seen in the West Kalimantan borderland, which stresses the fact that borderland communities are far from homogenous. Sturgeon contends that borders 'are nodes for the collection and distribution of resources, and the role of small border chiefs is implicated in and even produced by state-making (2004:466).' As stressed by Sturgeon, I believe that the examination of resource access and how it is negotiated between state authorities and local authorities provides an especially good starting point for understanding everyday forms of state formation in the resource-rich borderlands of Southeast Asia. In these marginal regions, natural resources are often the focus of negotiations between local authorities and the state.

In line with the more general debates on borders and the regional debates on Southeast Asian borderlands in particular, the book thus advocates a more benign approach to understanding the relationship between state institutions and local populations along borders. Such an approach does not solely portray borderland populations as resisting state intrusion but captures the intricate ways in which state and local factors are intertwined. Thus, these relationships can be both beneficial and constructive as well as negative and destructive for the actors involved. On the other hand by recognizing local strategies in exploiting the 'nooks and crannies' of the border, this study does not want to discard the importance of internal inequality within the borderland and the larger regulatory powers of the state. State regulatory powers along borders are in constant flux, and they can be suppressive and signify inequality for some segments of local society, but they can also constitute rewarding opportunity structures for others. What makes borderlands intriguing is the manner in which people living there both subvert and support their state. At times they fall victim to state power, while at other times they see the state as a means of gaining authority and wealth (Haller and Donnan 2000:12). The anthropological study of the everyday lives of border communities thus simultaneously becomes the study of the daily life of the state (Wilson and Donnan 1998a). 
Building on the basic propositions of states, borders, and borderlands, this study has wider implications for the debates on regionalism and local politics within a decentralizing Indonesia. Decentralization generally refers to the process in which central government relocates political, administrative and economic authority to lower-level regional governments like districts. The process is said to make government more transparent and accountable to its local constituencies and to result in better governance. ${ }^{19}$ However, debates indicate that decentralization processes in Indonesia are more complex and do not necessarily result in heightened transparency as originally envisioned by policymakers. ${ }^{20}$ Obviously, processes of decentralization are general phenomena throughout Indonesia, but as will be elaborated, the configuration of the borderland gives the phenomena a unique shape here.

The drastic changes in the wake of the economic and political crisis and President Soeharto's fall from power in 1998 quickly changed the dynamics of local politics in the borderland. In an attempt to distribute political and economic power more evenly and give authority back to the districts, a reckoning with more than thirty years of highly authoritarian and centralized system of governance under Soeharto, several new and shifting Indonesian 'reform' governments began initiating national programs of decentralization. Regional autonomy became the main topic, and new legislation resulted in a series of reforms that gave local districts increased autonomy over government sectors such as forestry. One of the initial intentions behind this strengthening of regional autonomy was to diminish separatist movements in previously marginalized resource-rich regions and thereby prevent a possible break-up of the country.

I will not here venture into the more technical discussion of decentralization laws and the various reforms they entail, but rather I will briefly point out a few developments within this transformation process that stand out as particularly interesting for the borderland case. First, within the Indonesian context, a large body of work has focussed on how these political transformations have affected the control of access to various resources in the marginal and resource-rich regions, especially

19 The Indonesian decentralization reforms have been portrayed as among the most radical worldwide (Aspinall and Fealy 2003a).

${ }_{20} \quad$ See Aspinall and Fealy 2003b; Schulte Nordholt and Van Klinken 2007b. 
highlighting the role of locally entrenched elites. ${ }^{21}$ Second, and linked to the above, is the creation of new administrative districts often headed by local elites motivated by their desire to enhance their authority over valuable local resources. ${ }^{22}$

What seems to be the overarching touchstone within these discussions is that decentralization has had profound effects on the configuration of state-society relations. While decentralization has resulted in the state becoming more personal and tightly embedded in local society and has empowered local people's participation in decision making, the shift has also engendered a great potential for enhanced collusion among wellconnected border elites, district officials and entrepreneurs. Lines of authority to a certain degree have been rearranged, but there are still considerable continuities with former arrangements of informal networks and alliances. Referring to the distinct patrimonial patterns of the former Soeharto regime, Schulte Nordholt and Van Klinken consider it misleading to view this regime as 'an integrated set of institutions operating primarily apart from society'. They instead argue for a critical re-evaluation of the distinctions between 'state' and 'society', 'formal' and 'informal' that are often invoked when referring to the New Order period in Indonesia (Schulte Nordholt and Van Klinken 2007a:8).

One can cite numerous examples of how regional elites who colluded with the former Soeharto regime have maintained their networks and still retain their roles in local polities in the post-Soeharto period of decentralization. In fact, these elites often have enhanced authority because of the increased local autonomy and the ability to bypass central state authorities. As noted by Schulte Nordholt and Van Klinken, 'Decentralisation comes into this world not as a deus ex machina but as a rearrangement of existing force fields' (2007a:2). In short, what these studies ultimately show is the continuity in informal networks as well as the way the reshuffling of authority has sharpened the struggle over resources on the local level since decentralization was introduced.

I have argued that borderlands create particular opportunities for local agency to arise and that processes of decentralization in Indonesia have created new opportunities for local (border) people to exercise their authority and influence formally (and informally) through political

${ }_{21}$ See Casson and Obidzinski 2002; McCarthy 2004; Morishita 2008; Resosudarmo 2003; Van Klinken 2008a, 2008b; Wollenberg et al. 2006.

${ }_{22}$ See Duncan 2007; Roth 2007; Vel 2007. 
engagement. Consequently, the distinction between local and state in the borderland studied is becoming further complicated, with local Iban entering government institutions, each with their own political agenda. ${ }^{23}$ It can be argued that the decentralization processes in Indonesia initiated in the late 1990s have created mass incentives for some segments of local society to capitalize on their newfound authority, especially those with a large network of influence reaching beyond the immediate local level. As demonstrated by Schulte Norholdt and Van Klinken, the rise of localism or regionalism set off by the decentralization process after the collapse of Soeharto's authoritarian regime, 'invites us to abandon the concept of the strong centralized state in favour of a model that offers room for a more fragmented polity' (2007a:3). They point out how such transformations: 'made certain hidden aspects of the state more explicit as it revealed the extent to which local actors used the state for their own interests' (2007:24).

\section{PATTERNS OF PATRONAGE AND THE 'BORDER EFFECT'}

Patron-client ties can be seen to arise within a state structure in which authority is dispersed and state activity limited in scope...(Weingrod 1977).

Michiel Baud and Willem van Schendel suggest that in order to understand the historic and social dynamics of borderlands we need to focus on the 'triangle of power relations' or overlapping networks between the state, regional elites and local people (Baud and Van Schendel 1997:219, 225). This 'triangle' of power is best understood by focusing on the perspective of patronage networks and alliance making on the border. ${ }^{24}$ More precisely, the book investigates how strategic access to the control of resources (in this case forest) is negotiated with various officials of the state and cross-border networks. In addition, by analyzing these relationships over time this study will take a historical approach that shows how the authority of border elites is the result of ongoing

23 See also Nancy Peluso's discussion of the conflicting demands faced and different roles played by local-level state officials in the struggle over access to forest resources on Java (Peluso 1992).

${ }_{24}$ The literature on patron-client relationships is too broad to be displayed here and it is beyond the scope of this study to engage in a larger theoretical discussion of the phenomena. For a more detailed discussion, see for example Eisenstadt and Roninger (1984, 1980), Gellner (1977) and Schmidt et al. (1977). 
negotiations and fraught relations with various state officials. In line with Schulte Nordholdt and Van Klinken, it is agreed that such 'networks of influence' are a useful entry point for analyzing the 'more personalized paradigms of state-society relations' (Schulte Nordholdt and Van Klinken 2007a:20).

It is important to note that the concept of patronage as applied in this book is somewhat different from the classic formulation that has been used in Southeast Asia and elsewhere. In their classic sense, patronclient dependency relations were mostly seen as static, exploitative and unsymmetrical. They were supposedly based on strict dependency relations between a patron and his clients, the patron often being a powerful landlord and his clients being landless peasants. According to James Scott, these kinds of 'feudal' patron-client relationships have since lost legitimacy and changed considerably to involve vertical links such as those between peasants and politicians (Scott 1972:6; 1977:125). Scott concludes that the structure of patron-client relationships in general is probably best understood as one that expands or contracts over time (1972:13). Furthermore, discourses related to extreme forms of exploitation and inequality have since been moderated to involve some degrees of reciprocity and the acknowledgment that 'weaker' peasants had certain 'weapons' of resistance; see, for example, Scott's analysis of landlordtenant relations in a Malay village (Scott 1985). Scott demonstrates that the conditions in Southeast Asia in general were quite favourable to the formation of patron-client relationships. However, the classic perspectives of patronage relations that emphasize extreme asymmetry and unbalanced bargaining power are not directly adaptable to the borderland context. Here patronage relationships function somewhat differently. I believe that seeing patron-client relations as merely asymmetrical 'dyadic ties' is too simplistic and does not account for the often very complex local bargaining positions and broader social and economic arrangements involved. While early studies of client-patron relations emphasized such dyadic relations, recent studies of patronage have taken an analytical shift and focussed on networks, factions, and coalitions.

As noted by Joel Kahn (1999) in his study of patronage relations in the uplands region of East Kalimantan, it is not possible to draw such clear distinctions between patrons and clients as local relations are much more egalitarian in regard to land distribution and social structure (compared to the often more stratified low land communities). A distinct 
class of landlords is difficult to recognize. The strictly asymmetrical view of patronage relations matches very poorly to the real-life categories of these upland populations. Here the border élites more often than not draw their authority and status from relationships and networks with powerful others such as state officials and wealthy entrepreneurs, not as large landlords (Kahn 1999:94-5). Hence one can see clear and important distinctions in the extent of restraints involved in a patron-client relationship.

Moreover, in the Iban case, the high value placed on personal autonomy and achievement has made such hierarchical dependency relations less obvious. As noted by Scott, certain marginal and upland regions of Southeast Asian states have only been 'intermittently subject to central government control' and operate with relative autonomy (Scott 1977:133). Although there are significant internal differences in wealth and status, no formal or traditional 'class' hierarchy or political organization exists within the Iban border communities. Only during Dutch colonialism were official hierarchies of 'tribal chiefs' introduced in order for the Dutch to influence authority indirectly over its inland subjects. Today local identity is mainly based on kinship ties. In pre-colonial West Borneo, small inland Malayu kingdoms did engage as patrons with various non-Malay communities, exchanging vital goods and services, although the kings were not landlords in a classical sense as their power was measured in the amount of followers not land ownership. However, the Iban was never part of this kind of asymmetrical patron-client relationship. Milne (1973:898-9) draws similar conclusions in reference to pre-colonial Iban communities living in Malaysia.

The Iban elite largely derive their position as brokers or patrons by their greater access to knowledge and personalized networks. Thus they become 'gatekeepers' (or brokers) as they link local communities with the outside world. They cannot directly exert power on local communities. In this context the relationship between patrons, brokers and clients is much more complementary as local communities (the clients) obtain a certain amount of bargaining power, although the relationship is still based on a certain degree of inequality.

Two basic analytical characteristics usually attributed to patronage networks are their inherent informality and seemingly illegal or semi-legal nature of relationships opposing official laws (Eisenstadt and Roniger 1980:50-1). The emergence of patronage networks is generally 
seen as a result of dysfunctional or absent strong state institutions. This view revolves around the assumption that when the state fails to provide basic services and social security, people seek such services through informal networks of reciprocity. Networks of patronage therefore appear most clearly entrenched at the edges of the state. Moreover, as will be demonstrated in the following chapters, such patronage relations are highly vulnerable to the challenge of countervailing socio-political forces, as they are not fully legitimized.

In an attempt to comprehend the recent booms of illegal timber logging in marginal regions of Indonesia after the onset of decentralization in the late 1990s, several authors have suggested that we look at the role of patronage networks. ${ }^{25}$ Krystof Obidzinski argues that the study of such dependency relations is thought to be important for understanding the misuse of political power and the structuring of the flow of resources in Indonesia (Obidzinski 2003:14-6). The studies mentioned here differ in that they are more localized and take a more benign approach. Many former studies emphasized the fraught relationships among higher-level political elites and neglected the more localized forms of patronage relations.

In his studies of the informal networks involved in illegal logging in Sumatra, John McCarthy $(2007,2006,2002)$ points out that understanding such often very personalized relationships is imperative for understanding the complexity behind these practices. He argues that informal networks become especially significant in marginal regions where formal institutions of the state are weakly constituted; central state rules that are imposed often are inconsistent with local traditions and lack local legitimacy. In these regions one detects a latent need for informal alternatives that can provide various services and fulfil needs normally delivered by the state (McCarthy 2006:14-7).

Patronage networks are developed to achieve certain goals in situations of public institutional uncertainty. The goals more often than not relate to access to valuable resources and benefits derived from these. In such circumstances, members of border elites (at the village and district level) often assume leadership positions and act directly as patrons either in a strict sense or through their influence as brokers between local villagers and higher-level patrons, or through a combination of both roles. In

${ }_{25}$ See Casson and Obidzinski 2002; McCarthy 2006; Obidzinski 2003; Wollenberg et al. 2006. 
the case of forest exploitation, border elites usually lack sufficient capital to undertake large-scale operations on their own, and they need financial and technical backup and support from higher-level patrons, including local and state officials (police, military etc.) and wealthy outside entrepreneurs (timber barons).

These relationships merge into what McCarthy calls 'clientelist coalitions' (or patron-broker-client bonds) (McCarthy 2002:81). ${ }^{26}$ The person acting as client is not only expected to make specific resources available to his patron but must also accept the patron's complete control over access to markets and over his capacity to convert resources. Similarly, the patron's position is not entirely solid or guaranteed. The patron's position is never fully legitimized and is therefore vulnerable to attack by social forces and by the competition of other patrons and brokers. Due to these constant threats, patrons are compelled to rely on their followers to solidify their position. The patron must also give up some short-term gains to protect public claims and to boost images of power and reputation. Sometimes this earns him the right to determine the basic rules of the social relationships. In return, the client is protected from social or material insecurity and is provided with goods, services, and at times social advancement (Roniger et al. 2001). Thus the mechanisms by which patronage work involve rules of reciprocity whereby the various actors engage in binding, although not legally enforceable, obligations of exchange, such as the flow of wealth, favours and support. ${ }^{27}$

This follows the perspective taken by another study on illegal logging in the province of East Kalimantan. Obidzinski (2003) notes how longterm, deeply entrenched patronage relationships there have changed from more traditional forms of patron-client relationships that involved highly asymmetrical power relations in which the client was highly dependent on his patron to something that more resembles 'cooperative, symbiotic, quid-pro-pro exchange relationships where individuals involved act as partners' (2003:18). According to Obidzinski local engagement in these patronage relationships was largely an attempt to meet certain localized economic subsistence and political needs (2003:33).

\footnotetext{
${ }_{26}$ The related terms clientelism and patronage are often used interchangeably. Clientelism often describes the logic of social exchange and the character of trust within patron-client relations, and patronage calls attention to the support granted by the patron to his followers and clients (Roniger et al. 2001:11118).

${ }_{27}$ In recent studies of Indonesian party politics the concept of clientelism has been employed as a way to understand the institutional complexity of politics after decentralization.
} 
In line with Obidzinski I believe that local engagement in networks of patronage should be analyzed as a localized coping strategy based on mutual respect and trust enacted in response to the shifting and unpredictable political and economic situation in the borderland. Although the prime mechanisms driving most parties within the networks are costbenefit calculations, and the main interest is economic advancement, their methodology is very much determined by local norms and values.

The face-to-face character of these relationships creates bonds of mutual trust and even friendship, which further enhance personal ties (Scott 1977:126). Such bonds of trust or interpersonal loyalty were developed in an extreme sense in the borderland in the 1970s when Iban elite figures 'adopted' Indonesian military officers as 'blood brothers' and three decades later similar bonds of trust were created with Malaysian timber barons. S.N. Eisenstadt and L. Roniger mention how such loyalty or solidarity can be closely related to local conceptions of honour and obligations (Eisenstadt and Roniger 1980:50). While this is very true in the borderland setting, I will also later spell out in greater detail how these bonds of trust often are of an ambivalent nature.

The Iban case clearly shows the persistence of these bonds. In the borderland, the Iban elite have for long acted as brokers or mediators between villagers (the clients) and various other actors, be they state officials, military or non-state individuals like powerful cross-border entrepreneurs (the patrons). In some relationships the border elite act as the patrons, being holders of, for example, logging concessions, while in other circumstances they are themselves clients to higher-level patrons. It is important to note that the redistribution of resources taking place in these networks involves a certain amount of inequality. In their role as brokers, border elites seem to secure their own personal interests and that of their nearest kin, while the degree of benefits reaching the village level is often limited. However, border elites, which include village heads, do not engage in patron-client relations solely for personal gain. For example, village heads must balance the expectations of them among close kin and needs and demands of the larger community. These patronage relationships spell out certain contradictions. They are characterised as being based on a combination of inequality/exploitation, mutual trust/ solidarity and voluntary cooperation.

What makes these border elites especially adept in taking on the mediating role is their capacity to move confidently between the village 
level, the regional level of district and province, and the transnational level. These networks build upon their multiple and strategic positions as local traditional leaders, district politicians, local-level entrepreneurs and their shared kinship ties extending across the border. Knowing the 'rules of the game' puts them in an ideal negotiating position with regard to the control of access to local resources. The extra-local network of these elites further makes such patronage systems extremely dynamic and easily adapted to sudden change in the local setting. Iban elites, for example, have been quick to take advantage of the uncertainties arising from recent political transformations of decentralization and to venture into relationships with local government and Malaysian entrepreneurs. Previously, their relationships had built upon ties with central state-based institutions like sections of Soeharto's military elite whose authority since the onset of decentralization dwindled in the borderland.

The book argues that the historically based networks of patronage on the border, based on illicit flows and the skill of strong and entrepreneurial men, may tell us interesting things about the advancement of Indonesian state formation. According to Thomas Gallant, the activities of such illegal networks largely facilitated the advancement of capitalism into remote border regions of the early modern state (Gallant 1999). Illegal socio-economic networks encouraged hinterland marketization and provided a venue for local upward economic mobility. The presence of these illegal networks often led by 'military entrepreneurs' (be they bandits, pirates, rebels, or ethnic chiefs) who 'literally and figuratively lived on the edge of society' has compelled national governments to sometimes violently intervene in an attempt to force their control on the border. ${ }^{28}$ These processes have largely facilitated the incorporation of these remote border regions into national polity - an outcome that Gallant terms the 'border effect' (Gallant 1999:48). The idea of the 'border effect' is useful in thinking the waxing and waning of state power on the West Kalimantan border.

The following chapters, for example, illustrate how border rebels, war chiefs, timber barons, gangsters, vigilantes, ethnic elites, and not least (predatory) military entrepreneurs worked the border, and how these 'men of prowess' in various ways contributed to the demarcation of the

28 Gallant (1999:26-7) does not refer to the formal institution: 'national army' when using the term 'military entrepreneurs'. Instead, he wishes to stress the tendency of these entrepreneurial men to 'take up arms' and apply the 'threat of violence' in their activities. 
territorial state. In particular, how they contributed to the continuous reproduction of the border through their ambivalent and shifting engagements with central state institutions. These engagements continuously fluctuated between processes of cooperation, collusion, and pacification and the outright defiance of central state authority. But most importantly, these processes show that such 'men of prowess', whose activities most often are deemed illegal, are not the antithesis of modern state formation but instead an integral part of it. As Gallant plainly stated, 'Bandits helped make states and states made bandits' (Gallant 1999:25).

\section{RULES AND NORMS AS PROCESSES OF NEGOTIATION}

What seems to connect the theoretical discussions cited above is the processual character of state-society relations and state formation in particular. Norms and rules are continuously shaped and reshaped in the contact between actors inside and outside the state apparatus. As a 'meta' analytical frame of this book, the insight of Sally Falk Moore's process-oriented theory is applied. Moore's concept of 'semi-autonomous social fields' is particular fruitful in explaining the dynamics of state-society relations in the borderland setting.

According to Moore, ethnographers should focus on change-in-themaking, such as process and events, and not assume an a priori existence of social structure and systems. For Moore change is a fluid process marked by unintended consequences that are difficult or impossible to estimate. She therefore questions whether 'a focus on regularity and consistency should not be replaced by a focus on change, on process over time, and on paradox, conflict, inconsistency, contradiction, multiplicity, and manipulability in social life?' (1975:217). Based on her study of local politics in Tanzania, Moore presents the assumption that 'indeterminacy' is a basic aspect of social life. In that regard, the underlying qualities of the organization of social life are basically 'temporary, incomplete, and contain elements of ambiguity, discontinuity, contradiction, paradox, and conflict' (1978:48-9). Socially generated rules and norms are in a process of flux as inconsistencies constantly are being questioned and manipulated.

In her process-oriented approach, Moore differentiates between 'processes of regularization' and 'processes of situational adjustment'. 
Accordingly, social life is undergoing a constant struggle between pressures of establishing or maintaining order and regularity, and the underlying messiness of social organization. This initially makes social life unsuited to complete ordering and regulation (Moore 1978:39). The situational or instance-by-instance use of rules permits the kind of reinterpretation, redefinition, and manipulation connected with so-called processes of situational adjustment.

By emphasizing the processes of regularization, situational adjustment, and the basic postulate of indeterminacy as an underlying quality of social life Moore attempts to explain the movement between efforts at establishing total or partial control and the unmanageable social forces that affect the first two. Furthermore, within this process-oriented approach the concept of a semi-autonomous social field takes a central position. By developing the notion of a 'semi-autonomous field', Moore attempted to advance an analytical perspective in understanding legal systems in particular and social change in general. While the study of law was a dominant factor in her studies, her analytical framework was not solely about 'law', but rather about normative fields in general (Moore 1978:55). Moore's idea of 'semi-autonomous fields' was at the time a contribution to a new and burgeoning approach within anthropology concerned with the interaction between different and often colliding legal orders and norms, an approach often referred to as 'Legal Pluralism'. According to Moore, a 'semi-autonomous social field' is not to be understood as a discrete organizational unit but as a network of social relationships.

A social field is semi-autonomous in the sense of being affected on one side by a 'larger social matrix' but also being able to draw on this matrix for its own ends on the other side. By introducing the notion of semi-autonomy, Moore attempts to mediate between notions of the state as all compassing and the existence of completely autonomous social fields. Neither of the two states of affairs seems to be applicable to social settings studied today. Moore investigated the extent to which social fields generate and enforce their own rules and the ways in which these fields influence and, in turn, are influenced by forms of regulation such as state laws. Sally Engle Merry notes that 'the outside legal system penetrates the field but does not dominate it; there is room for resistance and autonomy' (Merry 1988:878). The semi-autonomous social field is thus a limited social arena where strong social groups of interdependent actors 
with the capability to generate their own rules and norms often have more power than state laws and regulations. That situation resembles the borderland dynamics studied here.

Moore argues that state legislation or other attempts to change social habits often fail to achieve their intended purposes; even when they succeed wholly or partially, they frequently carry with them unplanned and unexpected consequences: 'This is partly because new laws are thrust upon social arrangements in which there are complexes of binding obligations already in existence' (1978:58). This perspective directs focus to the dialectic and mutually constitutive relations between state law and other normative orders, and, more importantly, emphasizes the interconnectedness of social orders.

The borderland as a social field brings together many different actors who engage in multiple and overlapping relations that generate their own rules and customs internally but are also affected by larger outside forces and rules surrounding it (Moore 1978:55). The borderland, or more precisely the whole complex of relationships portrayed in local patronage networks that it encompasses, can be considered as a semi-autonomous social field. What constitute this semi-autonomous social field are the processes through which state rules and laws are being continuously negotiated and challenged in the shifting relationship between state actors and border communities. This book argues that the process of 'mutual adjustments' between state rules and local norms, the ongoing negotiation over authority and definitions of legality and illegality makes the concept applicable to the borderland setting.

Omar M. Razzaz has, for example, identified several ways in which actors operating within a semi-autonomous social field may evade conforming to state laws and authority. First, actors within a social field can produce their own internal rules that could hinder the penetration of external rules. Second, they can avoid state laws by taking advantage of loopholes in the laws or inconsistencies in the enforcement procedures (Razzaz 1994). As will be demonstrated in the following chapters, the borderland has been shaped by a number of external forces but at the same time the borderland and its population have managed to maintain a certain amount of 'legal' semi-autonomy. ${ }^{29}$

Focusing on recent efforts to theorize that the concept of the state

${ }_{29}$ This is the concept applied by Fernanda in analyzing the semi-autonomous social field of a Ladakhi village (Fernanda 2006). 
that highlight its fragmented character, some argue that international borders provide an exceptionally good arena for studying state formation processes and the creation of nationhood along margins. This framework indicates that the region on the territorial border of state control brings certain qualities of the state into view that counter the popular idea of the state as an all-encompassing and unitary structure. By applying this framework, with its focus on process and networks, to the Indonesian setting, I hope to provide the means of overcoming the conceptual straitjacket of the state. As we shall see in the next chapter that discusses colonial encounters on the border, the relationship between state and local actors in the Indonesian borderlands has continuously shifted between processes of accommodation and resistance.

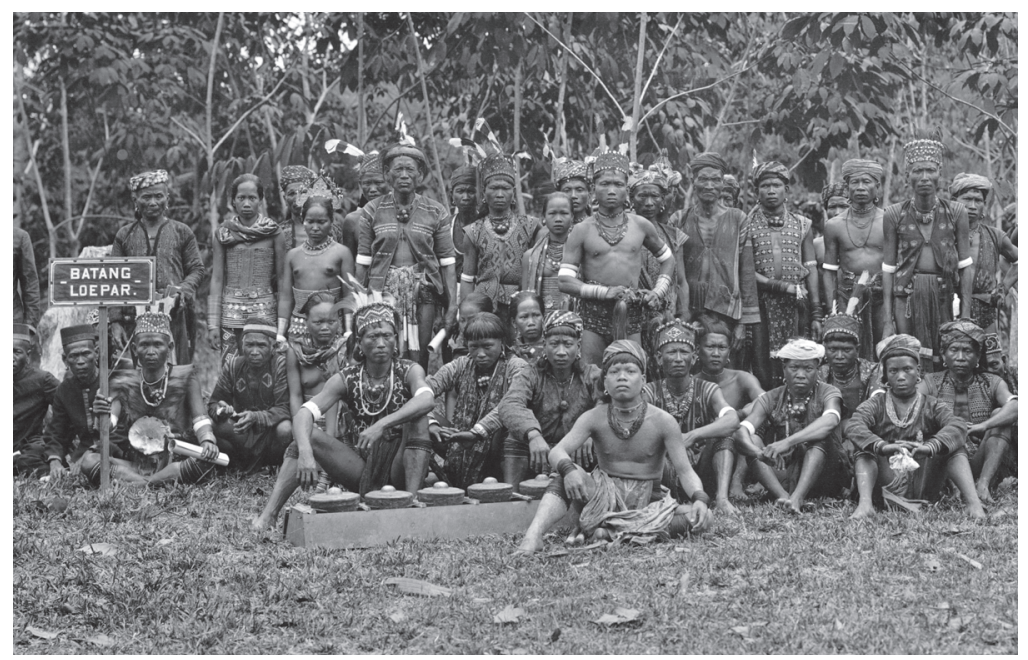

Fig 13: A group of Batang Lupars, 1920 (Photo courtesy KITLV, Leiden) 


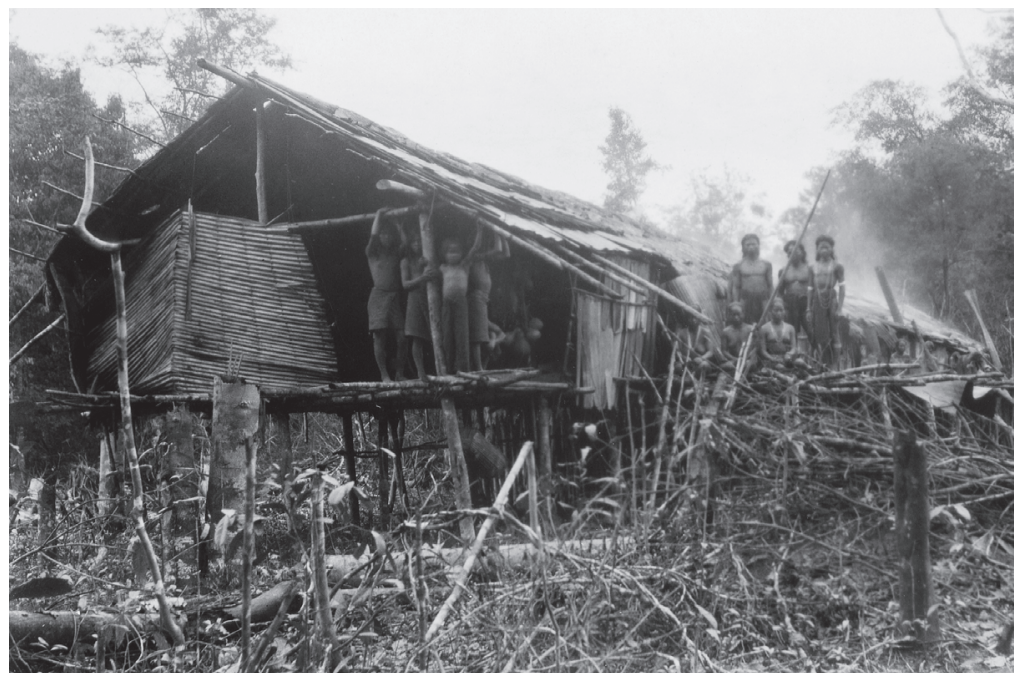

Fig 14: Temporary longhouse (dampa) in the vicinity of Nanga Badau, 1932 (Photo courtesy Koninklijk Instituut voor de Tropen, Amsterdam)

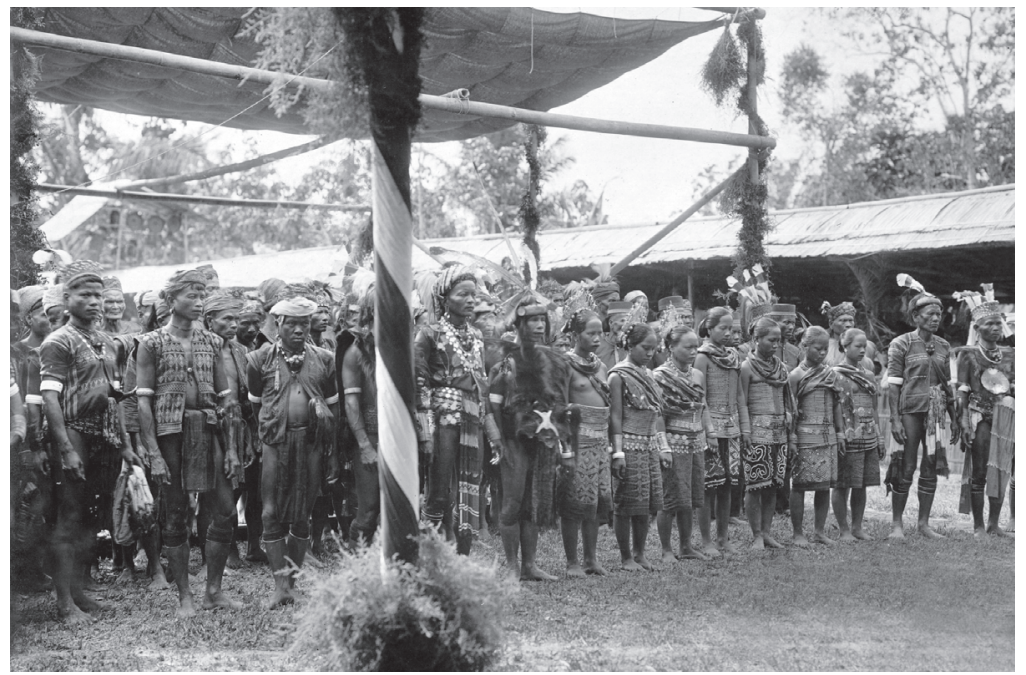

Fig 15: Batang Lupars parading at a visit by Governor-General Limburg van Stirum, 1920 (Photo courtesy KITLV, Leiden) 


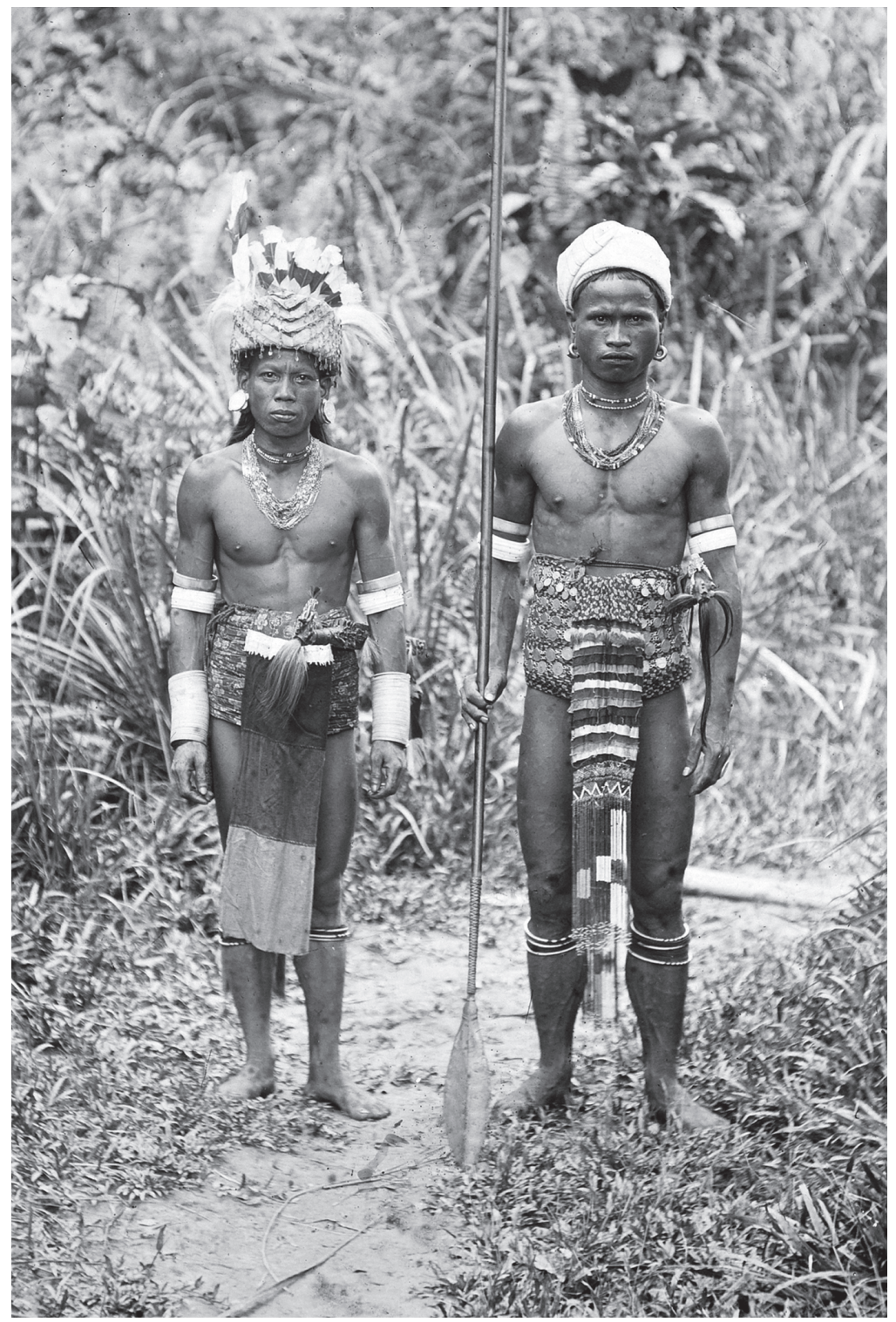

Fig 16: Batang Lupars in full wardress (date unknown; probably early twentieth century) (Photo courtesy Koninklijk Instituut voor de Tropen, Amsterdam) 


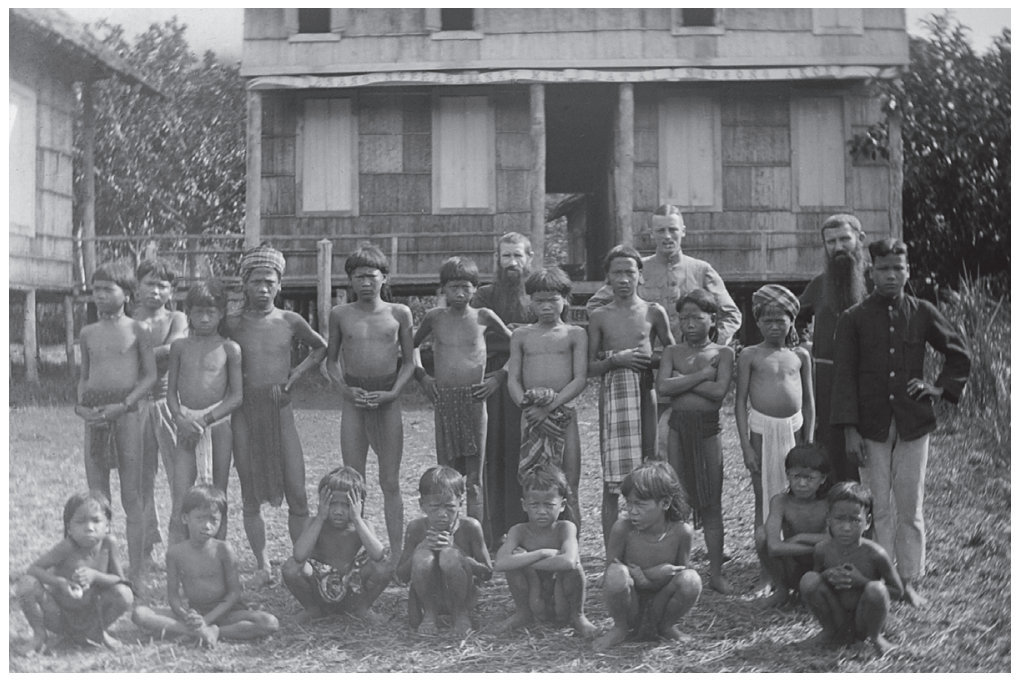

Fig 17: Catholic school in Lanjak (date unknown; probably early twentieth century) (Photo courtesy Koninklijk Instituut voor de Tropen, Amsterdam)

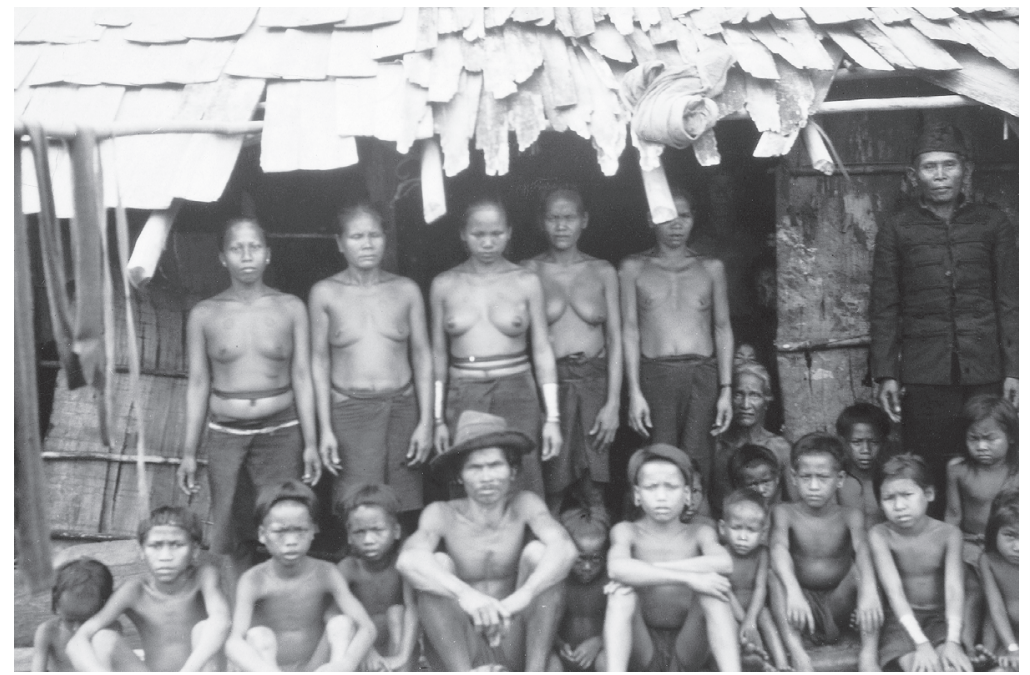

Fig 18: Temenggong (right) in soldiers's uniform, Batang Loepar Kampong Rongga, 1932 (Photo courtesy Koninklijk Instituut voor de Tropen, Amsterdam) 


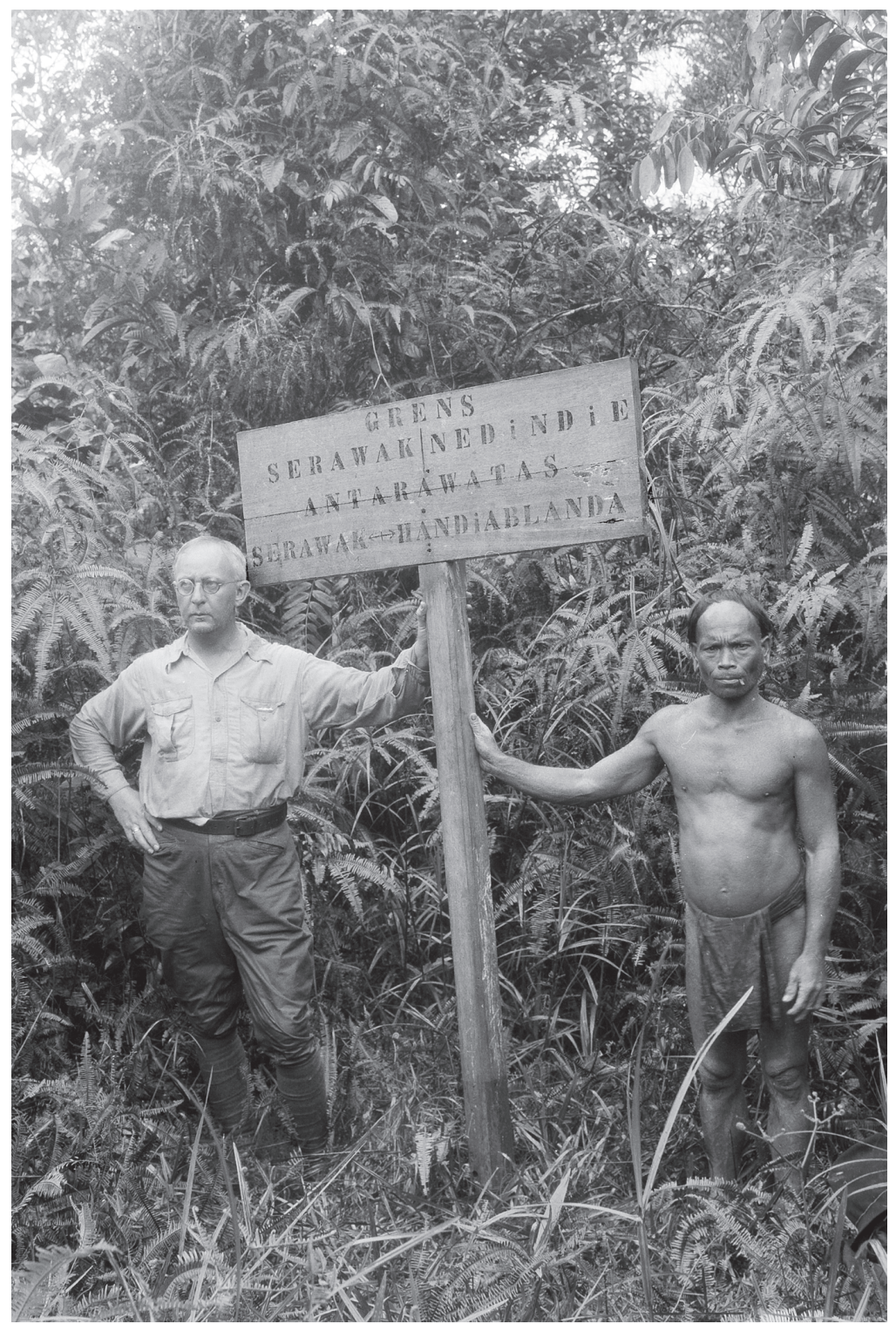

Fig 19: Consultant ir. G.A. de Mol and Iban headman on the border between Dutch West Borneo and Sarawak, 1932 (Photo courtesy Koninklijk Instituut voor de Tropen, Amsterdam 